\title{
Nucleolar organiser regions: new prognostic variable in breast carcinomas
}

\author{
E Sivridis, B Sims
}

\begin{abstract}
Nucleolar organiser regions (NORs), which are important for regulating protein synthesis, were identified in 20 breast carcinomas by means of a silver (Ag) staining technique. Infiltrating neoplasms with metastases in four or more axillary lymph nodes possessed, on average, a greater number of AgNORs per cell nucleus compared with neoplasms without nodal disease, or with one to three positive lymph nodes. The size, morphology, and distribution of AgNORs within the nucleus were also different in the two study groups. Overall, these findings suggest that breast carcinomas with multiple, irregular, and widely dispersed AgNORs tend to be of high grade malignancy.
\end{abstract}

Nucleolar organiser regions (NORs) are loops of DNA that are responsible for ribosomal RNA (rRNA) transcription. ${ }^{1}$ They are located in the nucleoli of cells and in the chromosomes $13-15$ and 21,22 in association with proteins. ${ }^{2-4}$ As rRNA molecules are the main sites of protein synthesis it follows that the number of NORs in each cell nucleus reflects cellular activity. ${ }^{45}$

Nucleolar organiser regions can be readily identified in paraffin wax sections by means of a silver $(\mathrm{Ag})$ staining technique (AgNOR) ${ }^{6}$ : they are visualised in the nuclei of cells as brown/black dots by virtue of the argyrophilia of NOR-associated proteins. ${ }^{7}$ These were thought to include proteins $B 23^{8}$ and $\mathrm{C} 23,{ }^{9}$ subunits of RNA polymerase $1,{ }^{10}$ and probably other phosphoproteins. The function of these molecules is still far from clear; they may partly reflect ploidy, ${ }^{11}$ though an increase in ploidy does not necessarily lead to an increase in AgNORs in human tumours. ${ }^{12-14}$

For years the AgNOR technique has been used by cytogeneticists for the investigation of certain genetic disorders, notably that of chromosome $21 .{ }^{15}$ The recent modification of the original method, ${ }^{6}$ however, became increasingly applied in histopathology research following suggestions that there may be a possible association between high AgNOR counts and malignant transformation. ${ }^{4616}{ }^{17}$ In this study we investigated the usefulness of the AgNOR technique in assessing the aggressiveness in breast carcinomas.

Methods

Tumour tissue blocks from 20 mastectomy specimens were selected at random from the files of the Department of Histopathology, General Hospital, Alexandroupolis. All specimens had been fixed in $10 \%$ formol-saline and processed routinely through absolute alcohol and xylene before embedding to paraffin wax (Paraplast). There were 14 infiltrating ductal carcinomas (of scirrhous, medullary, and mucinous variants), two infiltrating lobular carcinomas, and four pure intraductol carcinomas.

The breast tumours were divided into two groups depending on the number of positive lymph nodes at the time of surgery. The first group comprised carcinomas in situ and infiltrating carcinomas without nodal disease or with metastases in up to three axillary lymph nodes (eight cases). The second group consisted of infiltrating breast neoplasms with metastases in four or more lymph nodes (12 cases). In every case at least 10 axillary nodes were examined histologically.

The modified AgNOR technique, as described by Ploton $e t$ al ${ }^{6}$ was applied to paraffin wax sections of $3 \mu \mathrm{m}$. AgNOR counts were performed blind and independently by two observers, using a standard procedure ${ }^{18}$ : in this, clusters of black dots within nucleoli are counted as one AgNOR; black dots dispersed throughout the nucleus are counted as discrete AgNORs. The mean numbers of AgNORs per cell nucleus (AgNOR clusters, dispersed AgNORs, and totals) was determined for each case after counting 100 nuclei directly on to tissue sections at $\times 400$ magnification. Cells were examined at random.

AgNOR counting was repeated subsequently, along the same lines, using projected transparencies; microphotographs had been taken randomly at magnifications of $\times 200$ and $\times 500$. Interobserver and intraobserver error were calculated.

The significance of results (mean numbers of AgNOR clusters plus dispersed AgNORs) was assessed by the Wilcoxon rank sum test.

\section{Results}

AgNORs were clearly visible on light microscopical examination as black silver binding dots within nuclei stained orange. There were, however, well defined differences between the two study groups of breast carcinomas. Thus malignant neoplasms without nodal disease or with metastases in less than four lymph nodes contained, on average, two to three AgNORs per cell nucleus (mean 2.81; median 2.65; SD $0.61 ; 95 \%$ CI $1.59-4.03)$ : these were uniform,
Correspondence to: Dr E Sivridis 


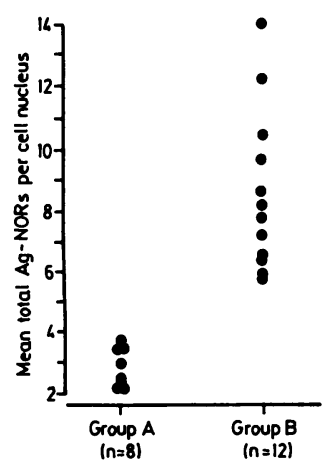

Scattergram showing mean total AgNOR numbers cell nucleus for each specimen of breast carcinoma examined.

\begin{tabular}{lcllc}
\hline & & \multicolumn{2}{l}{ Mean AgNOR count } \\
\cline { 2 - 5 } Lymph node state & No of cases & AgNOR clusters & Dispersed AgNORs & Totals \\
\hline Negative nodes or one to three positive nodes & 8 & 1.97 & $0 \cdot 84$ & 2.81 \\
Four or more positive nodes & 12 & $2 \cdot 24$ & 6.33 & $8 \cdot 57$ \\
\hline
\end{tabular}

round, and dense. By contrast, AgNORs in breast carcinomas with four or more positive nodes were usually, though not invariably, of bizarre morphology and more numerous: up to three large, often irregular, dense structures and multiple smaller argyrophilic dots, less distinct and widely dispersed within the nucleus (mean 8.57 AgNORs/nucleus; median 8.00 ; SD 2.63; $95 \%$ CI 3.30-13.72). The results are expressed as a scattergram in the figure; the difference between the two study groups was significant $(\mathrm{p}<0.001$ ), although the numbers are too small to be able to detect clinically important differences. The intra- and inter-observer error was between $4 \cdot 1$ and $6.3 \%$. The correlation between AgNOR counts by the two methods of enumeration was good: $r=0 \cdot 8$. The table shows the patterns of AgNOR staining and their mean values per tumour cell nucleus. AgNOR counts, though highly reproducible by both methods, were more easily accomplished in projected photographic transparencies.

\section{Discussion}

The prognosis of primary breast carcinoma depends on several morphological and endocrinological variables. These include: tumour size; type of tumour; the degree of differentiation into glandular or tubular structures; the presence, degree, and prevalence of nuclei showing hyperchromatism, pleomorphism, and mitotic activity; the degree of lymphocytic response; the presence of local invasion and lymph node metastases; and the tumour receptor state. ${ }^{19-22}$ Although these various factors are evaluated in combination, in practice the most important single factor in determining prognosis seems to be the extent of disease at the time of operation. ${ }^{23-25}$ Microscopic evidence of metastases in four or more axillary lymph nodes is associated with a higher percentage of treatment failure and a lower incidence of five year survival, compared with cases where nought to three lymph nodes are affected. ${ }^{192326-28}$

The morphological expression of this prognostic determinant may well be the silver-binding NOR-associated proteins of the cell nucleus. Thus as the present study suggests, there seems to be a relation between AgNOR counts and the number of positive lymph nodes in breast carcinomas: the higher the numbers and the more bizarre the morphology of AgNORs in the primary tumour, the more extensive the nodal disease. The reasons for this tendency are obscure but may be related to an increased nuclear activity. ${ }^{429}$

It is tempting to speculate, therefore, that the numbers, the shape, and the distribution of AgNORs within the nucleus might be of poten- tial use in predicting behaviour in breast carcinomas. This would be very convenient for assessing aggressiveness in small incisional biopsy specimens, needle aspiration cytology, or imprint cytology. The validity of such an assumption, however, could only be verified by a large series of patients participating in long term follow up studies. ${ }^{30}$

In other tissues and disease states claims that the AgNOR activity is of prognostic value have not been warranted by the rather scanty and contradictory reports. ${ }^{1831}$ Equally, suggestions that the method may be helpful in discriminating benign from malignant disease or in distinguishing between low and high grade malignancy have been found to be the case in some studies, ${ }^{45163233}$ but not in others. ${ }^{34-37}$ Further studies are clearly needed before the clinical importance of the AgNOR staining method can be fully appreciated.

We thank Mr P Smith, Chief MLSO, Department of Histopathology, East Birmingham Hospital, for his invaluable technical assistance in respect to the AgNOR silver staining technique, and Mrs C Price for her secretarial assistance.

1 Fakan S, Hernandez-Verdun D. The nucleolus and the nucleolar organizer regions. Biol Cell 1986;56:189-206.

2 Ferguson-Smith MA, Handmaker SD. Observations on the satellited human chromosomes. Lancet 1961;i:638-40.

3 Lewin B. Gene expression. 2. In: Eucaryotic chromosomes. 2nd ed. New York: John Wiley, 1980:875-8.

4 Crocker J, Nar P. Nucleolar organizer regions in lymphomas. J Pathol 1987;151:111-8.

5 Smith R, Crocker J. Evaluation of nucleolar organizer region-associated proteins in breast malignancy. Histopathology 1988;12:113-25.

6 Ploton D, Menager M, Jeanesson P, Himber G, Pigeon F, Adnet J-J. Improvement in the staining and in the visualization of the argyrophilic proteins of the nucleolar organizer region at the optical level. Histochem J 1986; 18:5-14.

7 Hubbell HR, Rothblum LI, Hsu TC. Identification of a silver binding protein associated with the cytological silver staining of actively transcribing nucleolar regions. Cell staining of actively transcribin
Biol Int Rep 1979;3:615-22.

8 Lischwe MA, Smetana K, Olson MOJ, Busch H. Proteins $\mathrm{C} 23$ and B23 are the major nucleolar silver staining proteins. Life Sci 1979;25:701-8.

9 Ochs R, Lischwe M, O'Leary P, Busch H. Localization of nucleolar phosphoproteins B23 and C23 during mitosis. Exp Cell Res 1983;146:139-49.

10 Williams MA, Kleinschmidt JA, Krohne G, Franke WW. Argyrophilic nuclear and nucleolar proteins of Xenopus laevis oocytes identified by gel electrophoresis. Exp Cell Res 1982;137:341-51.

11 Trent JM, Carlin DA, Davies JR. Expression of silver stained nucleolar organizing regions (AgNORs) in human cancer. Cytogenet Cell Genet 1981;30:31-8.

12 Giri DD, Nottingham JF, Lawry J, Dundas SAC, Underwood JCE. Silver-binding nucleolar organizer regions (Ag-NORs) in benign and malignant breast lesions: correlations with ploidy and growth phase by DNA flow cytometry. J Pathol 1986;57:307-13.

13 Derenzini M, Pession A, Farabegoli F, Trere D, Badiali M Dehan P. Relationship between interphasic nucleolar organizer regions and growth rate in two neuroblastoma cell lines. Am J Pathol 1989;134:925-32.

14 Crocker J, Janmohamed RMI, Armstrong SJ, Hulten M, Leyland MJ. The relationship between numbers of interphase NORs and NOR-bearing chromosomes in nonphase NORs and NOR-bearing chromosomes

15 de la Cruz FF, Gerald PS. Trisomy 21. Baltimore: University Park Press, Gerald PS.

16 Croker J, Skilbeck N. Nucleolar organizer region associated proteins in cutaneous melanotic lesions: a quantitative 
study. J Clin Pathol 1987;40:885-9.

17 Fallowfield ME, Dodson AR, Cook MG. Nucleolar organizer regions in melanocytic dysplasia and melanoma. Histopathology 1988;13:95-9.

18 Howat AJ, Giri DD, Wright AL, Underwood JCE. Silverstained nucleoli and nucleolar organizer region counts are of no prognostic value in thick cutaneous malignan melanoma. J Pathol 1988;156:227-32.

19 Russo J, Frederick J, Ownby HE. Predictors of recurrence and survival of patients with breast cancer. Am J Clin Pathol 1987;88:123-31.

20 Martin SA, Perez-Reyes N, Mendelsohn G. Angioinvasion in breast carcinoma. An immunohistochemical study of factor VIII-related antigen. Cancer 1987;59:1918-22.

21 Rank F, Dombernowsky P, Jespersen NCB, et al. Histologic malignancy grading of invasive ductal breast carcinoma. malignancy grading of invas

22 Alexieva-Figusch J, van Putten WLJ, Blankestein MA, et al. The prognostic value and relationships of patient characteristics, estrogen and progestin receptors, and site of relapse in primary breast cancer. Cancer 1988;61:758-68.

23 Fisher B, Glass A, Redmond C, et al. L-Phenylalanine mustard (L-PAM) in the management of primary breas cancer: An update of earlier findings and a comparison of the utilizing L-PAM plus 5 fluorouracil ( 5 FU). Cancer 1977;39:2883-903.

24 Nemoto T, Vana J, Bedwani RN, et al. Management and survival of female breast cancer: Results of a national survey by the American College of Surgeons. Cancer 1980; 45:2917-24.

25 Fisher B, Bauer M, Wickerham I, Redmon CK, Fisher ER Relation of number of positive axillary nodes to prognosis of patients with primary breast cancer. Cancer 1980 52:1551-7.

26 Fisher ER, Gregorio R, Redmond C. Pathologic findings from the National Surgical Adjuvant Breast Project (Protocol N. 4). II. The significance of regional node histology other than sinus histiocytosis in invasive mammary cancer. Am J Clin Pathol 1976;65:21-30.
27 Primary Therapy of Breast Cancer Study Group. Identification of breast cancer patients with high risk of early tion of breast cancer patients with high risk of early recurrence after radical mastectomy. II. Clinical

28 Carter CL, Allen C, Henson DE. Relation of tumour size, lymph node status, and survival in 24,740 breast cancer cases. Cancer 1989;63:181-7.

29 Crocker J, Macartney JC, Smith PJ. Correlation between DNA flow cytometric and nucleolar organizer region data in non-Hodgkin's lymphomas. J Pathol 1988;154:151-6.

30 Brown RA, Beck JS. Statistics on microcomputers: A nonalgebraic guide to the appropriate use of statistical packages in biomedical research and pathology laboratory practice. 6 Statistical methods for diagnostic tests. J Clin Pathol 1989;42:225-30.

31 Egan M, Raafat F, Crocker J, Williams D. Comparative study of the degree of differentiation of neuroblastoma and mean numbers of nucleolar organiser regions. J Clin Pathol 1988;41:527-31.

32 Egan M, Raafat F, Crocker J, Smith K. Nucleolar organizer regions in fibrous proliferations of childhood and infantile fibrosarcoma. J Clin Pathol 1988;41:31-3.

33 Egan MJ, Crocker J. Nucleolar organizer regions in cutaneous tumours. J Pathol 1988;154:247-53.

34 Nairn ER, Crocker J, McGovern J. Limited value of AgNOR enumeration in the assessment of thyroid neoplasms. J Clin Pathol 1988;41:1136.

35 Howat AJ, Giri DD, Cotton DWK, Slater DN. Nucleolar organizer regions in Spitz nevi and malignant melanomas. organizer regions in Sp
Cancer 1989;63:474-8

36 Giri DD, Dundas SAC, Sanderson PR, Howat AJ. Silverbinding nucleoli and nucleolar organizer regions in fine needle aspiration cytology of the breast. Acta Cytol 1989;33:173-5.

37 Giri DD, Nottingham JF, Lawry J, Dundas SAC, Underwood JCE. Silver-binding nucleolar organizer regions (AgNORs) in benign and malignant breast lesions: correlations with ploidy and growth phase by DNA flow cytometry. J Pathol 1989;157:307-13. 